\title{
KEMAMPUAN NETRALISASI KEKEBALAN TUBUH INDUK MELALUI KUNING TELUR AYAM PETELUR PADA VIRUS AI (H5N1) ISOLAT LAPANGAN
}

\section{MATERNAL ANTIBODY'S NEUTRALIZATION ABILITY IN LAYER CHICKEN'S EGG YOLK ON FIELD OF AI H5N1 VIRUS}

\author{
AP Haryanto ${ }^{1 a}$, RD Soedjono ${ }^{2}$, dan S Murtini ${ }^{3}$ \\ 1Program studi Peternakan Fakultas Pertanian Universitas Djuanda Bogor, Jl. Tol Ciawi No. 1, Kotak \\ Pos 35 Ciawi, Bogor 16720. \\ 2 Guru Besar Mikrobiologi - Imunologi, dan Dosen Bagian Ilmu Penyakit Hewan dan Kesehatan Masyarakat Veteriner Fakultas \\ Kedokteran Hewan, IPB \\ ${ }^{3}$ Dosen Virologi, Bagian Ilmu Penyakit Hewan dan Kesehatan Masyarakat Veteriner Fakultas Kedokteran Hewan IPB \\ aKorespondensi: Agung Puji Haryanto, E-mail: agung.puji@unida.ac .id
}

(Received: 10-10-2020; Accepted: 13-10-2020)

\begin{abstract}
Day old chick in the first week of their life got the immunity from maternal antibody / immunoglobulin trough egg yolk. Hens with high antibody titer will decended the immunoglobulin to their harvest trough egg yolk. The research studied the capability of antibody anti H5N1 from egg yolk to neutralized AIV. Twenty hens were devided to five group: one group as a control group were unvaccinated group, and four other groups were vaccinated with H5N1 AI inactive vaccine produced by several Indonesia vaccines company. Four H5N1 AI inactive vaccines code VS1, VC1, VV1 and VM1 were vaccinated twice to group 2, 3, 4 and 5. A week after second vaccination of the egg were collected and analyzed the antibody titer against H5N1 by hemagglutination of test using H5N1 field isolates as standard virus (NG and LW)). The egg yolk were contain high antibody titer (above 26) collected and tested against H5N1 field isolates NG and LW by serum neutralization test. The result showed that H5N1 NG isolate were able to neutralized by antibody anti H5N1 from egg yolk produced by hens vaccinated with VS1, VC1, VV1 and VM1, but LW isolate were able to neutralized by showed that H5N1 NG isolate were able to neutralized by antibody anti H5N1 from egg yolk produced by hens vaccinated with VS1, VC1, and VM1. It's concluded that hens were vaccinated with H5N1 AI inactive vaccine were able to protect their harvest against H5N1 from the field by transferred maternal antibody trough the egg yolk with titer above 26.
\end{abstract}

Keywords : antibody, inactive vaccines, egg yolks.

\begin{abstract}
ABSTRAK
Anak ayam umur sehari (DOC) selama masa hidupnya hingga umur 7 hari mendapatkan imunitas dari kekebalan induknya/immunoglobulin melalui kuning telur. Induk ayam yang memiliki titer kekebalan tinggi akan menurunkan immunoglobulin melalui kuning telur. Penelitian ini bertujuan mengetahui dan menganalisa kemampuan kekebalan anti H5N1 dari kuning telur untuk menetralisir virus AI subtype H5N1, sehingga mampu melindungi anak ayam dari infeksi virus lapangan pada masa awal pemeliharaan. Pada penelitian ini menggunakan ayam induk 20 ekor, yang dibagi menjadi 5 kelompok; satu kelompok sebagai control, tidak divaksinasi, dan 4 kelompok lainya divaksinasi dengan vaksin AI H5N1 inaktif yang diproduksi perusahaan vaksin di Indonesia. Empat kelompok divaksinasi AI H5N1 inaktif 2 kali diberikan kode VS1, VC1,VV1, dan VM1 (kelompok 2,3,4, dan 5). Seminggu setelah vaksinasi kedua, pengumpulan telur dan dianalisa titer antibody anti H5N1dengan tes hemaglutinasi menggunakanisolat H5N1 lapangan sebagai virus standar (NG dan LW). Kuning telur dikumpulkan diuji dengan serum netralisasi (SNT) H5N1 isolat lapangan NG dan LW dengan titer antibody (diatas 26). Hasil tersebut menunjukan bahwa virus AI subtype H5N1 isolat NG dapat dinetralisasi dengan antibody anti H5N1 dari kuning telur yang diproduksi oleh induk telah
\end{abstract}


divaksinasi dengan VS1,VC1,VV1, dan VM1. Kesimpulan yang dapat diambil bahwa induk yang telah divaksinasi dengan vaksin inaktif AI H5N1 dapat mencegah serangan virus AI subtype H5N1 dari lapangan, dengan transfer kekebalan induk melalui kuning telur (titer diatas 26).

Kata kunci: antibody, vaksin inaktif, kuning telur.

AP Haryanto, RD Soedjono, S Murtini. 2020. Kemampuan Netralisasi Kekebalan Tubuh Induk Melalui Kuning Telur Ayam Petelur Pada Virus AI (H5N1) Isolat Lapangan. Jurnal Peternakan Nusantara 6(2): 89-96.

\section{PENDAHULUAN}

Penyakit unggas menular Avian Influenza (AI) merupakan famili Orthomyxoviridae, tipe A. Karakteristik dan pategenitasnya menyebabkan penyakit hingga kematian pada ayam. Virus AI terdiri dua jenis yaitu Low Pathogenic Avian Influenza (LPAI) dan High Pathogenic Avian Influenza (HPAI) (Dharmayanti et.al 2020). AI disebabkan oleh beberapa serotype bersifat endemis dibeberapa negara misalnya di Tiongkok, Vietnam, Mesir, Pakistan, dan Indonesia, sehingga tindakan stamping out untuk semua wilayah tidak mudah dan efektif dilakukan, sehingga negara memilih vaksinasi guna strategi pengendalian penyakit (Wibawan 2017). Teknologi produksi vaksin AI antara lain; vaksin konvensional (Inaktif Homolog dan Heterolog) dan vaksin rekombinanasi (aktif (vektor virus lain) dan pasif (reverse genetic))) (Zarkasie 2018).

Kekebalan pasif merupakan kekebalan yang diturunkan dari induk ke anaknya melalui kuning telur, sebagai perlindungan awal setelah menetas. Ayam memiliki Imunoglobulin (Ig) Y, A, dan M. Hal tersebut terdapat IgY, tapi tidak IgA atau IgM. Kekebalan induk diturunkan ke kuning telur, sebagai pertahanan awal anak ayam sampai umur $1-2$ minggu. (Hamal et. al. 2006).

Titer kekebalan tubuh induk tinggi, akan menurunkan kekebalan pasif ke anaknya sehingga dapat bertahan. Kemampuan netralisasi kekebalan tubuh induk pada anak ayam, infeksi AI H5N1 lapangan saat ini belum diketahui. Studi mengetahui daya proteksi kekebalan tubuh dapatan infeksi AI H5N1 dilapangan perlu .

\section{MATERI DAN METODE}

\section{Materi}

Penelitian dilaksanakan di Laboratorium Terpadu Bagian Mikrobiologi Medik, Bagian Ilmu Penyakit Hewan dan Kesehatan Masyarakat Veteriner, Fakultas Kedokteran Hewan, Institut Pertanian Bogor.

Penelitian menggunakan 25 ekor ayam ras petelur, umur 22 minggu

(siap

bertelur). Vaksin yang digunakan penelitian ini adalah vaksin H5N1 inaktif komersial produksi dalam negeri. Terdapat 4 jenis vaksin tersebut digunakan yaitu dengan kode VS1, VC1, VV1 dan VM1. Penelitian ini menggunakan antigen H5N1 sebagai virus standar pada uji penghambatan hemaglutinasi (HI). Jenis antigen $\mathrm{H} 5 \mathrm{~N} 1$ digunakan adalah antigen $\mathrm{H} 5 \mathrm{~N} 1$ isolat $\mathrm{A} / \mathrm{C} / \mathrm{NG}$ dan A/C/LW yang telah diinaktivasi.

\section{Perlakuan}

Ayam tersebut dibagi menjadi 5 kelompok, terdiri dari 5 ekor ayam. Kelompok pertama tidak divaksinasi, merupakan kelompok kontrol. Kelompok kedua divaksinasi AI H5N1 inaktif komersial berkode VS1. Kelompok ketiga divaksinasi AI H5N1 inaktif komersial berkode VC1. Kelompok keempat divaksinasi AI H5N1 inaktif komersial berkode VV1, sedangkan kelompok kelima divaksinasi AI H5N1 inaktif komersial berkode VM1.

\section{Rancangan Percobaan}

Data dianalisa secara deskriptif dengan menghitung indek netralisasi masing-masing pengenceran.

\section{Prosedur Pelaksanaan}

Ayam petelur ras Isa Brown umur 22 minggu, diperiksa terlebih dahulu titer kekebalan tubuhnya terhadap $\mathrm{H} 5$ dengan uji HI menggunakan kedua jenis antigen tersebut diatas. Hasil uji HI ini digunakan dasar 
menentukan vaksinasi yang akan dilakukan. Vaksinasi dilakukan ketika hasil uji HI dari ayam yang akan digunakan titernya lebih rendah dari $2^{2}$. Ayam bertiter Ab terhadap AInya rendah selanjutnya dibagi dalam lima kelompok seperti diuraikan diatas. Vaksinasi dilakukan sebanyak dua kali dengan interval satu bulan. Seminggu setelah vaksinasi kedua setiap 7 hari ayam diambil darahnya untuk diperiksa titer kekebalan tubuhnya terhadap H5 dengan uji HI menggunakan kedua jenis antigen. Pada saat titer kekebalan tubuhnya minimum $2^{7}$ maka telurnya mulai dikumpulkan setiap hari.

Pengumpulan Antibodi Asal Induk dari Kuning Telur

Telur dari induk yang telah divaksin dikumpulkan dan diperiksa kekebalan tubuh dalam kuning telur terhadap AI H5. Kuning telur yang telah mengandung kekebalan tubuh terhadap AI dengan titer diatas $2^{5}$ selanjutnya dikumpulkan berdasarkan kelompok dan hari pemanenan. Kuning telur tersebut dimasukan ke tabung mikro (microtube) dan disimpan pada suhu $-20^{\circ} \mathrm{C}$ sampai saat akan digunakan. Koleksi kuning telur dalam microtube diencerkan menggunakan PBS pH 7,4, perbandingan 1:1. Suspensi kuning telur divortex sampai homogen. Supernatan dari suspensi kuning telur tersebut selanjutnya diuji titer antibodinya terhadap H5.

\section{Uji Hemaglutinasi (HA) Mikrotitrasi}

Virus yang digunakan sebagai standar ditentukan titernya/dititrasi menggunakan uji HA. Virus AI H5 yang digunakan sebagai virus standar pengujian adalah isolat NG dan LW yang merupakan isolat lapang. Prosedur HA (OIE 2004). Berdasarkan titer yang diperoleh virus stok yang dititrasi diencerkan menjadi 4 HAU yang selanjutnya digunakan pada uji penghambatan agglutinasi (Uji HI).

\section{Pemeriksaan Antibodi Anti AI H5 dengan Uji Penghambatan Aglutinasi (Heamagglutination Inhibition Test/HI Test)}

Penentuan titer kekebalan tubuh anti AI H5 pada serum ayam petelur maupun kuning telur dilakukan dengan uji HI menurut metode OIE (2004).
Tabel 1 Panel Uji HI Kuning Telur Pada Masing-Masing Kelompok

\begin{tabular}{|l|c|c|c|c|c|}
\hline \multirow{2}{*}{\multicolumn{1}{c|}{ Antigen }} & \multicolumn{6}{|c|}{ Kelompok Kuning Telur } \\
\cline { 2 - 6 } & & $\mathrm{VS}$ & $\mathrm{VC}$ & $\mathrm{VV}$ & $\mathrm{VM}$ \\
& $\mathrm{K}$ & 1 & 1 & 1 & 1 \\
\hline \multirow{2}{*}{$\mathrm{A} / \mathrm{C} / \mathrm{NG}$} & $\sqrt{ }$ & $\sqrt{ }$ & $\sqrt{ }$ & $\sqrt{ }$ & $\sqrt{ }$ \\
\hline & & & & & \\
A/C/LW & $\sqrt{ }$ & $\sqrt{ }$ & $\sqrt{ }$ & $\sqrt{ }$ & $\sqrt{ }$ \\
\hline
\end{tabular}

$\mathrm{V}$ : nilai titer yang diperoleh dalam uji panel

\section{Uji Serum Netralisasi}

Kemampuan kekebalan tubuh yang terdapat dalam kuning telur untuk menetralkan virus AI diuji serum netralisasi. Uji serum netralisasi dilakukan terhadap kuning telur dari masing-masing kelompok dengan virus isolat lapang $(\mathrm{A} / \mathrm{C} / \mathrm{NG}$ dan $\mathrm{A} / \mathrm{C} / \mathrm{LW})$. Titer virus yang digunakan $10^{6}$ sampai dengan $10^{3}$ EID $_{50}$. Uji serum netralisasi ini menggunakan telur ayam berembrio bebas kekebalan tubuh $\mathrm{H} 5$ (Spesific Antibody Negative) umur 10 hari. Uji serum netralisasi menggunakan metode $\alpha$ dan dihitung dengan metode Reed-Muench. Pada uji ini virus diencerkan sedangkan titer kekebalan tubuh tetap. Rancangan uji serum netralisasi disajikan pada Tabel 2 .

Tabel 2 Panel Uji Serum Netralisai Kuning Telur Pada Masing-masing Kelompok

\begin{tabular}{|c|c|c|c|c|c|}
\hline \multirow{2}{*}{$\begin{array}{c}\text { Antigen } \\
\text { dan } \\
\text { pengenceranny } \\
\text { a }\end{array}$} & \multicolumn{5}{|c|}{ Kelompok Kuning telur } \\
\hline & $\mathrm{K}$ & $\begin{array}{l}\mathrm{V} \\
\mathrm{S} 1\end{array}$ & $\begin{array}{l}\mathrm{V} \\
\mathrm{C} 1\end{array}$ & $\begin{array}{l}\mathrm{V} \\
\mathrm{V} \\
1\end{array}$ & $\begin{array}{l}\mathrm{V} \\
\mathrm{M} 1\end{array}$ \\
\hline $\mathrm{A} / \mathrm{C} / \mathrm{NG}$ & \multicolumn{5}{|c|}{$\begin{array}{l}\text { Jumlah Inokulasi Telur } \\
\text { (butir) }\end{array}$} \\
\hline $10^{6}$ & 3 & & & & \\
\hline $10^{5}$ & 3 & 3 & 3 & 3 & 3 \\
\hline $10^{4}$ & 3 & 3 & 3 & 3 & 3 \\
\hline $10^{3}$ & & 3 & 3 & 3 & 3 \\
\hline $\mathrm{A} / \mathrm{C} / \mathrm{LW}$ & \multicolumn{5}{|c|}{$\begin{array}{l}\text { Jumlah Inokulasi Telur } \\
\text { (butir) }\end{array}$} \\
\hline $10^{6}$ & 3 & & & & \\
\hline $10^{5}$ & 3 & 3 & 3 & 3 & 3 \\
\hline $10^{4}$ & 3 & 3 & 3 & 3 & 3 \\
\hline $10^{3}$ & & 3 & 3 & 3 & 3 \\
\hline
\end{tabular}




\section{HASIL DAN PEMBAHASAN}

Pada program vaksinasi efektif, seleksi strain seed virus sebagai vaksin merupakan bagian untuk mendapatkan perlindungan maksimal, yang hanya dapat dicapai bila ada kecocokan antara antibodi dengan antigen bersirkulasi lapang. Pada virus AI kecocokan terutama terhadap antigen HA-nya karena antigen tersebut merupakan target utama dari sistem kekebalan. Virus RNA bermutasi cepat pada protein HE dan NE. Mutasi tersebut dapat menyebabkan perubahan antigenitas, sehingga membuat vaksin tidak efektif (Cai et. al. 2010). Keragaman antigen virus HPAI H5N1 tidak mempersulit pengembangan vaksin tetapi juga permasalahan diagnostik, karena antigen tunggal (antiserum) diduga tidak dapat mendeteksi semua sampel isolat lapangan H5N1 (Ducatez et.al. 2011).

Tidak efektifnya vaksinasi ini disiasati oleh perusahaan vaksin dengan menggunakan virus seed vaksin tertentu pada setiap produksinya. Hal tersebut menyebabkan adanya perbedaan virus seed vaksin pada produk vaksin di Indonesia. Virus seed vaksin umumnya diseleksi, memiliki kesamaan antigenik dengan virus yang bersirkulasi di lapang. Seleksi strain virus seed vaksin influenza memilih virus, dengan kecocokan karakteristik antigenik dan genetik. Karakterisasi strain virus seed vaksin melalui sekuensing suatu isolat, tidak tergatung hasil dari karakterisasi antigenik. Salah satu bentuk karakterisasi antigenik adalah homologi antar antigen di lapang (virus isolat lapang) dengan kekebalan tubuh, diinduksi oleh antigen virus seed vaksin yang digunakan.

Uji HI digunakan mengukur jarak antara dua antigen melalui uji serologi antara antigen dengan antiserum standar yang sama. Misalnya, jika salah satu uji antigen merupakan reaktor tinggi untuk antiserum standar (contoh : titer 320) sementara antigen uji yang lain reaktor rendah (contoh : titer 40). Jarak antigenik dapat mencapai 3 unit, dengan pengenceran log2 (320/40). Jarak antigen diukur dengan antisera standar, sehingga perhitungannya relatif rumit. Penghitungan data HI digunakan menentukan jarak antar antigen standar dengan antigen yang diuji. Kartografi sebagai analogi geografis digunakan untuk menggambarkan dan mengukur jarak antigenik dari virus influenza. Kriteria penting vaksin influenza merupakan antigen yang berbeda (contoh: 4 kali lipat perubahan pada uji HI). Kartografi antigenik Influenza dapat membantu kita

mengidentifikasi apakah pengujian antigen (virus) adalah isolate virus berbeda jauh dari strain spesifik vaksin atau cluster antigen spesifik (misalnya : sirkulasi strain pada periode waktu tertentu). (Cai et. al. 2010).

Pengujian titer kekebalan tubuh anti H5 kuning telur menggunakan antigen standar virus $\mathrm{H} 5 \mathrm{~N} 1$ isolat $\mathrm{NG}$ dan $\mathrm{LW}$ menunjukkan adanya kekebalan tubuh pada kelompok yang divaksinasi. Titer kekebalan tubuh di kuning telur pada minggu ke 6 setelah vaksinasi tersebut cukup tinggi yaitu mencapai $2^{7,6}$ sampai $2^{8}$ antigen isolat NG dan $2^{6,2}-2^{7,8}$ antigen isolat LW. Semua jenis vaksin komersial yang digunakan mampu menginduksi terbentuknya kekebalan tubuh bertiter tinggi. Perbedaan seed virus dari masing-masing vaksin tidak mempengaruhi pembentukan kekebalan tubuh. Titer kekebalan tubuh dalam kuning telur, ketika diuji HI menggunakan virus standar isolat LW memberikan hasil berbeda dengan virus standar isolat NG pada waktu setiap pengamatannya. Perbedaan tersebut tidak melebihi selisih titer $2^{2}$, sehingga dinyatakan antigen vaksin secara antigenik kartografi tidak berbeda dalam keragaman karakteristik antigeniknya.

Berdasarkan kartografi antigenik dalam peta antigenik, jarak antara titik anti serum $\mathrm{S}$ dan titik antigen $\mathrm{A}$ sesuai dengan perbedaan antara $\log -2$ dari maksimum titer yang diamati untuk anti serum $\mathrm{S}$ terhadap setiap antigen dan log-2 dari titer antiserum untuk $S$ terhadap antigen A, hal tersebut masih memiliki kesamaan fenotipe (Fouchier et. al. 2012). Hasil pengujian semua kekebalan tubuh anti AI di kuning telur menunjukan hasil vaksinasi keempat kelompok dengan antigen isolate NG maupun LW yang tidak sampai $2^{2}$, maka dapat diklasifikasikan bahwa belum ada perubahan fenotipe antara kedua antigen tersebut.

Kartografi antigenik pada virus AIV digunakan sebagai identifikasi varian antigenik dan seleksi strain vaksin influenza. Kartografi antigenik Influenza analog dengan kartografi geografi. Hal tersebut memproyeksikan antigen influenza kedalam peta 2 dimensi berdasarkan titernya. Jarak antar antigen dapat diukur seperti jarak geografis pada peta geografis (Ducatez 2011). 

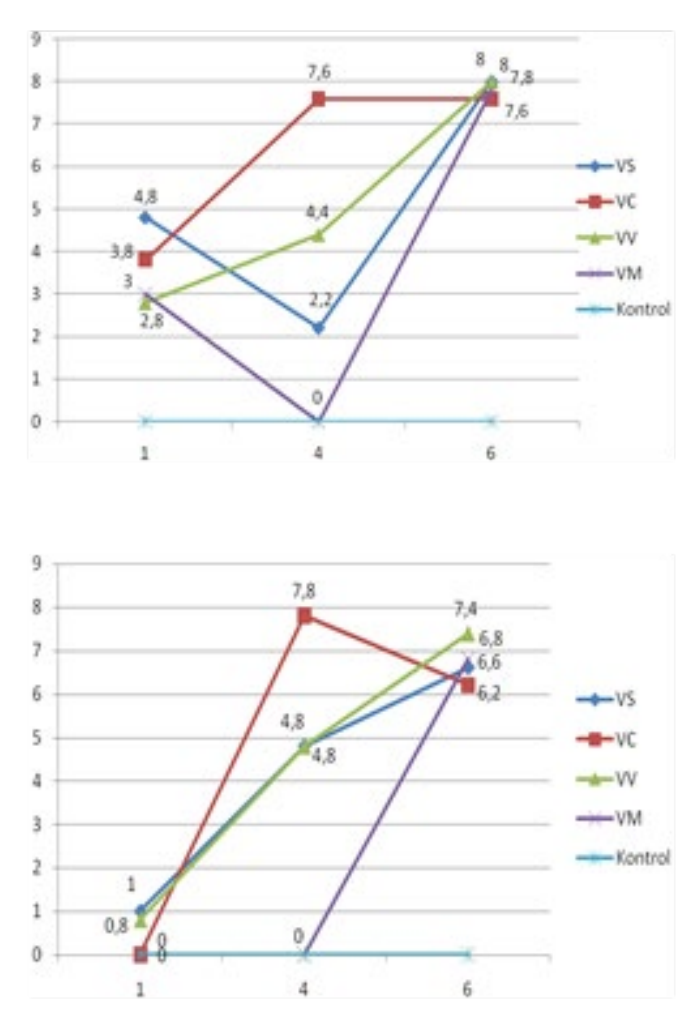

Gambar 1 Titer Antibodi Koleksi Telur Pasca Vaksinasi Kedua Diuji dengan Antigen Isolat NG (kiri) dan LW (kanan)

Pada gambar 1., bahwa 7 hari pasca booster vaksinasi kekebalan tubuh dalam serum sudah mulai berpindah ke kuning telur. Hal itu ditandai munculnya kekebalan tubuh terhadap H5 pada ayam yang divaksinasi. Sedangkan pada ayam kontrol tidak muncul kekebalan tubuh tersebut. Hasil ini sama dengan pernyataan Chalghoumi et. al. (2009), bahwa serum mengandung IgY secara selektif ditransfer dari induk melalui sistem sirkulasi darah melalui oolema ke oosit dewasa dalam folikel di ovarium. Transfer IgY tersebut melalui reseptor spesifik pada permukaan membran kantung kuning telur dimana dapat mentransportasikan semua sub populasi IgY induk.

Berdasarkan gambaran titer kekebalan tubuh di kuning telur, tampak bahwa kekebalan tubuh induk cukup tinggi baru diturunkan pada 6 minggu pasca vaksinasi ke-dua.

\section{Pengujian SNT}

Uji netralisasi serum merupakan uji identifikasi antigen dan kekebalan tubuh dengan melihat kemampuan netralisasi kekebalan tubuh (Ab) terhadap antigen (Ag). Uji netralisasi virus (serum netralisasi) lebih sensitif untuk mendeteksi kekebalan tubuh spesifik H5 dan terutama lebih spesifik pada kekebalan tubuh dalam mendeteksi virus influenza sampai tingkat strain (Okuno et.al.1990). Namun, tidak terdapat protokol standar mendeteksi penetralisasi antibodi yang ada, karena korelasi kekebalan terhadap perlindungan tubuh tidak dapat ditentukan secara pasti. Vaksin yang menghasilkan titer antibodi, belum tentu mampu menetralisasi virus lapang. Hal tersebut seharusnya ditangani bagian dari strategi untuk mengembangkan vaksin yang cocok terhadap AI.

Pengamatan kemampuan kekebalan tubuh diinduksi vaksin inaktif AI strain lokal Indonesia, dalam menetralkan virus $\mathrm{AI}$ lapangan. Uji netralisasi serum ini menggunakan metode $\alpha$ yaitu kekebalan pada kuning telur konsentrasinya konstan, sedangkan virus tantangnya diencerkan. Menurut FOHI (2007) standar indeks netralisasi suatu vaksin dinilai protektif bila nilainya lebih dari $2\left(10^{2}\right)$.

Tabel 3 Hasil Pengujian Netralisasi Serum

\begin{tabular}{|c|c|c|c|c|}
\hline \multirow{2}{*}{$\begin{array}{l}\text { KELOMPOK } \\
\text { SAMPEL }\end{array}$} & \multicolumn{2}{|c|}{$\begin{array}{c}\text { Titer Virus }(\log 10) \\
\text { EID }_{50} \\
\end{array}$} & \multicolumn{2}{|c|}{$\begin{array}{c}\text { INDEKS } \\
\text { NETRALISASI }\end{array}$} \\
\hline & NG & LW & NG & LW \\
\hline SN & 6 & 7 & 0 & 0 \\
\hline VS1 & 2,5 & 2 & 3,5 & 5 \\
\hline VM1 & 2,55 & 2 & 3,45 & 5 \\
\hline $\mathrm{VC} 1$ & 3,5 & 2 & 2,5 & 5 \\
\hline VV1 & 2,75 & 5,5 & 3,25 & 1,5 \\
\hline
\end{tabular}

Vaksin-vaksin yang telah diuji dengan antigen isolat NG. Kelompok vaksin (VS1, VM1, VC1 dan VV1) bersifat protektif ditunjukan dengan tingginya angka indeks netralisasi yaitu lebih dari 2.

Pada antibodi kuning telur asal keempat kelompok vaksin ketika diuji dengan antigen isolat LW, VS1, VM1 dan VC1 bersifat protektif, karena memiliki indeks netralisasi diatas 2, sedangkan kelompok VV1 indeks netralisasinya hanya 1,5. Pada uji HI, titer kekebalan tubuh di kuning telur tinggi. Namun, kekebalan tubuh tersebut tidak mampu menetralisasi virus H5N1 strain NG. Hasil ini sejalan dengan penelitian Kaverin et. al. (2002) yang mengamati adanya beberapa reaksi yang tidak biasa antara 
monoklonal $\mathrm{Ab}$ antiprotein asam sialik dari virus AI H3 dengan virus H3 yaitu adanya resistensi terhadap netralisasi sehingga masih meninbulkan infektivitas pada kultur sel. Hasil pemeriksaan antigen tersebut dengan metode ELISA mampu mengikat kekebalan induk yang diuji.

Netralisasi virus mampu menjadikan adanya indikasi infeksi virus secara in-vitro tidak berhasil, akibat adanya kekebalan tubuh mengikat antigen sehingga target tidak mampu menempel pada penerima sel inang. Kekebalan tubuh menghambat terjadinya interaksi antara virus dengan inang. Hal tersebut menghalangi proses infeksi saat virus menempel pada permukaan inang.

Imunoglobulin Y (IgY) pada ayam bertiter $2^{4}$ mampu menetralisasi $100 \%$ virus H5N1 isolat 2005. Wibawan et. al. (2009). Penelitian ini menyatakan bahwa titer IgY menetralkan strain NG dan LW, bertiter lebih tinggi yaitu $2^{6}$. Perbedaan tingkat efikasi beberapa faktor, diantaranya adalah adanya perbedaan konformasi dan konsentrasi kekebalan tubuh (IgY). Telur memiliki konsentrasi IgY berkisar antara 50-100 mg/butir telur dengan jumlah antibodi spesifik antara $2-10 \%$. Perbedaan antigen dalam pengujian mempengaruhi kemampuan netralisasi serum. Hasil pengujian Kaverin et al. (2002) yang membuktikan kekebalan tubuh monoklonal terhadap antigen protein asam amino 26 (virus AI H5). Ketika dititrasi dengan uji $\mathrm{HI}$, memiliki titer rendah, tetapi diuji dengan netralisasi kekebalan tubuh monoklonal tersebut mampu menghambat infeksi virus. Hasil pengamatan Kaverin et al. (2002) tersebut menganalisa adanya dua bagian asam amino 26 dari virus AI yaitui epitop cp 58 dan 176, epitop cp 58, tidak dapat diikat oleh kekebalan induk tersebut hanya epitop 176 dan epitop 176-lah. Sampel uji menunjukan titer HI lebih rendah namun efektivitas netralisasi lebih baik.

\section{KESIMPULAN DAN IMPLIKASI}

\section{Kesimpulan}

Hasil penelitian tersebut menunjukan bahwa kandungan kuning telur terdapat kekebalan tubuh terhadap AI subtipe H5N1. Hasil vaksinasi vaksin komersial Indonesia mampu menetralisasi virus lapang isolat NG dan LW. Vaksin berkode VV1 menetralisasi virus lapang isolat NG. Titer kekebalan tubuh dalam kuning telur $\left(>2^{6}\right)$, mampu menetralisasi virus isolat lapang.

\section{Implikasi}

Kuning telur dikembangkan sebagai sebagai sampel deteksi tingkat keberadaan kekebalan tubuh induk yang diturunkan kepada anak ayam (DOC). Penentuan tepat waktu vaksinasi untuk memperoleh kekebalan tubuh induk protektif anak ayam pada final stock.

\section{DAFTAR PUSTAKA}

Cai Z, T. Zhang, XF. Wan. 2010. A Computation Framework for Influenza Antigenic Cartography. J.Oct 2010.Vol.6.www.ploscompbiol.org.

Chalghoumi R, Beckers Y, Portetelle D, Théwis A. 2009. Hen Egg Yolk Antibodies (IgY), Production and Use For Passive Immunization Against Bacterial Enteric Infections In Chicken: A Review. J. Biotechnol. Agron. Soc. Environ. 2009 13(2), 295-308.

Dharmayanti NLP. Indriani R, Nurjanah D . 2020. Vaccine Efficacy on The Novel Reassirtrnant H9N2 Virus in Indonesia. Article. MDPI. Vaccines 2020,8,449

Direktorat Jendral Peternakan [DITJENNAK. 2007. Farmakope Obat Hewan Indonesia (FOHI). Jilid I (Sediaan Biologik). Ed ke-3. Jakarta: Direktorat Jenderal Peternakan Departemen Pertanian RI.

Ducatez MF, Z. Cai, M. Peiris, Y. Guan, Z. Ye, XF. Wan, RJ. Webby. 2011. Extent of Antigenic Cross-Reactivity Among Highly Pathogenic H5N1 Influenza Viruses. Journal of Clinical Microbiology. Oct 2011, p.3531-3536.

Fouchier, RAM, S. Herfst, A.D. M. E. Osterhaus. 2012. Public Health and Biosecurity Restricted Data On Influenza H5N1 Virus Transmission. Science 10. February 2012 : Vol. 335 no. 6069 pp. 662-663. DOI: 10.1126/science. 1218376

Hamal KR, Burgess, Pevzner, Erf GF. 2006. Maternal Antibody Transfer from Dams to Their Egg Yolks, Egg Whites, and Chicks in Meat Lines of Chickens. Immunology, Health, 
And Disease. Poultry Science Association. Poult Sci 2006. 85:1364-1372.

Kaverin NV, Rudneva IA, Ilyushina NA, Varich NL, Lipatov AS, Smirnov YA, Govorkova EA, Gitelman AK, Lvov DK, Webster RG. 2002. Structure of Antigenic Sites on the Haemagglutinin Molecule of H5 Avian Influenza and Phenotypic of Escape Mutants. Journal of Virology.83, 2497-2505.

Office International des Epizooties [OIE]. 2004. Avian Influenza. Chapter 2.7.12. Manual of Diagnostic Test and Vaccines for Terrestrial Animals. Paris: OIE.

Okuno Y, Tanaka K, Baba K, 1990. Rapid Focus Reduction Neutralization Test Of Influenza A And B Viruses In Microtiter System. J Clin Microbiol ; 28:1308-13.],.
Wibawan IWT, 2017. Virus Avian Influenza dan Alternatif Pengembangan Vaksin. Artikel Ilmiah. Infovet Nov 2017.

Wibawan IWT, Murtini S, Soejoedono RD, Mahardika IGNK. 2009. Produksi IgY Antivirus Avian Influenza H5N1 dan Prospek Pemanfaatannya dalam Pengebalan Pasif. Jurnal Veteriner. Vol.10.No.3.

Zarkasie K. 2018. Comprehensive Prevention Programe For New Wave of Avian Influenza. Article. ADHPI. Indolivestock Seminar 2018. 
